medRxiv preprint doi: https://doi.org/10.1101/2021.11.18.21266535; this version posted November 19, 2021. The copyright holder for this preprint (which was not certified by peer review) is the author/funder, who has granted medRxiv a license to display the preprint in perpetuity.

\title{
Uptake of Covid-19 vaccines among frontline workers in California state prisons
}

Lea Prince, $\mathrm{PhD}^{1}$; Elizabeth Long, MS ${ }^{1}$; David M. Studdert, LLB, $\mathrm{ScD}^{1,2}$; David Leidner, $\mathrm{PhD}^{3}$, Elizabeth T. Chin, BS ${ }^{4}$; Jason R. Andrews, MD, MS ${ }^{5}$, Joshua A. Salomon, $\mathrm{PhD}^{1}$, Jeremy D. GoldhaberFiebert, $\mathrm{PhD}^{1}$

Author Affiliations:

(1) Department of Health Policy, Stanford University School of Medicine, and the Freeman Spogli Institute, Stanford University, Stanford, CA, USA

(2) Stanford Law School, Stanford, CA, USA

(3) Independent (affiliation pending approval)

(4) Department of Biomedical Data Science, Stanford University, Stanford, CA, USA.

(5) Department of Medicine, Stanford University School of Medicine, Stanford, CA, USA

Corresponding Author:

Lea Prince, $\mathrm{PhD}$

Stanford Health Policy and Department of Medicine

Stanford University School of Medicine

117 Encina Commons

Stanford, CA, 94305

lcprince@stanford.edu

(ph) 650-723-4582 


\begin{abstract}
Background

Prisons are high-risk environments for Covid-19. Vaccination levels among prison staff remain troublingly low - lower than levels among residents and members of the surrounding community. The situation is troubling because prison staff are a key vector for Covid-19 transmission.
\end{abstract}

\title{
Objective
}

To assess patterns and timing of staff vaccination in California state prisons and identify individual- and community-level factors associated with being unvaccinated.

\section{Design}

We calculated fractions of prison staff and incarcerated residents in California state prisons who remained unvaccinated. Adjusted analyses identified demographic, community, and peer factors associated with vaccination uptake among staff.

\section{Setting}

California Department of Corrections and Rehabilitation prisons.

\section{Participants}

Custody and healthcare staff who worked in direct contact with residents.

\section{Main Outcomes and Measures}

Remaining unvaccinated through June 30, 2021.

\section{Results}

A total of $26 \%$ of custody staff and $52 \%$ of healthcare staff took $\geq 1$ dose in the first two months of vaccine offer; uptake stagnated thereafter. By June 30, 2021, $61 \%$ of custody and $37 \%$ of healthcare staff remained unvaccinated. Remaining unvaccinated was positively associated with younger age, prior Covid-19, residing in a community with relatively low vaccination rates, and sharing shifts with coworkers who had relatively low vaccination rates.

\section{Conclusions and Relevance}

Vaccine uptake among prison staff in California in regular contact with incarcerated residents has plateaued at levels that pose ongoing risks - both of further outbreaks in the prisons and transmission into 
medRxiv preprint doi: https://doi.org/10.1101/2021.11.18.21266535; this version posted November 19, 2021. The copyright holder for this preprint (which was not certified by peer review) is the author/funder, who has granted medRxiv a license to display the preprint in perpetuity. All rights reserved. No reuse allowed without permission.

surrounding communities. Staff decisions to forego vaccination appear to be complex and multifactorial. Achieving safe levels of vaccine protection among frontline staff may necessitate requiring vaccination as condition of employment.

\section{Funding Source}

Supported in part by the Covid-19 Emergency Response Fund at Stanford, established with a gift from the Horowitz Family Foundation; a grant (R37-DA15612), awarded to Dr. Goldhaber-Fiebert and Dr.

Salomon, from the National Institute on Drug Abuse; a grant (NU38OT000297-02), awarded to Dr. Salomon, from the Centers for Disease Control and Prevention through the Council of State and Territorial Epidemiologists; a grant (DGE-1656518), awarded to Ms. Chin, from the National Science Foundation Graduate Research Fellowship Program. 
medRxiv preprint doi: https://doi.org/10.1101/2021.11.18.21266535; this version posted November 19, 2021. The copyright holder for this

\section{Introduction}

Prisons and jails are particularly high-risk environments for Covid-19. Since the pandemic began, there have been more than 550,000 Covid-19 cases among residents and staff in carceral settings in the United States, nearly 3,000 deaths, and infection rates among residents are 4-5 times higher than those in the general community.(1-5) In California state prisons alone, approximately one in four residents have had Covid-19 and 241 have died.(6,7) Correctional staff are likely to be a significant source of introduction of SARS-CoV-2 infection into prisons. $(4,8)$

Beginning in December 2020, California prioritized prison residents and employees for Covid-19 vaccination. Nine months later, three-quarters of residents had elected to receive at least one dose, but only $60 \%$ of employees working with direct physical access to the residents had done so. Nationally, Covid-19 vaccine coverage rates among prison staff have been lower than rates in the wider community. To redress this situation, the federal government and several states, including California, have introduced mandates, prompting lawsuits and staff resignations.(9-11)

Vaccine hesitancy among workers in high-risk settings, like prisons, is not well understood. We analyzed uptake of Covid-19 vaccines among more than 31,000 staff in California's state prisons. The study goal was to describe patterns of vaccination in this population and identify individual and workplace characteristics associated with low vaccine uptake.

\section{Methods}

\section{Data}

The California Department of Corrections and Rehabilitation (CDCR) provided anonymized person-day level data. The data included comprehensive information on PCR and antigen testing and vaccination for both prison staff and residents (January 1, 2020 through June 30, 2021), plus additional information on incident cases among residents through September 25, 2021. The staff data also included information on demographic characteristics, zip code of home residence, and which shifts each staff member worked at which prison. Statistics on SARS-CoV-2 infection by zip codes came from California Department of 
medRxiv preprint doi: https://doi.org/10.1101/2021.11.18.21266535; this version posted November 19, 2021. The copyright holder for this

Public Health (CDPH) data. Stanford's institutional review board approved the study (protocol numbers IRB-55835, IRB-55671).

\section{Study Sample}

The study focused on correctional staff who worked in CDCR prisons between the date vaccines were first offered to staff (December 22, 2020) through June 30, 2021. Thus, the study period ended before proposals for and debate over mandatory vaccination for prison staff flared in California; this period also predated the Delta variant surge (see Appendix for more detail). We restricted the analytic sample to staff who worked 5 or more shifts between April 1, 2021 (by which time vaccines were available to any staff member who wanted one) and June 30, 2021, were employed with a designation of custody or healthcare (excluding contract employees), and worked in roles that involved regular direct contact with residents (“direct care"). Two of CDCR's 35 prisons were excluded from the analysis due to missing or incomplete staff data at those prisons. Staff with missing values for variables of interest $(<1 \%$ of those who met the above eligibility criteria) were dropped from the analysis.

\section{Variables}

The outcomes of interest in our primary analyses were indicator variables denoting staff and residents who had not been vaccinated by the end of the study period. In secondary analyses, we also considered indicators denoting staff and residents who were neither vaccinated nor had history of SARS-CoV-2 infection.

Being unvaccinated was defined as having received no doses of a Covid-19 vaccine. No history of SARS-CoV-2 infection was defined as having no confirmed positive result from a PCR or antigen test. CDCR's staff testing program has involved a combination of mandatory and voluntary testing; most of the testing has been routinely performed by CDCR itself, although early on, some results from staff tests obtained elsewhere were included. CDCR's resident testing program consists of routine risk-based and surveillance testing and testing in response to detected outbreaks. $(12,13)$ 
medRxiv preprint doi: https://doi.org/10.1101/2021.11.18.21266535; this version posted November 19, 2021. The copyright holder for this

The demographic information on staff members included age group, racial or ethnic group, gender, recorded zip code of residence, and whether the individual had any history of SARS-CoV-2 infection.

To explore the relationship between staff members' vaccination status and two potential environmental influences - lack of vaccine uptake in communities in which they lived and among fellow workers - we created two additional variables. First, we used the CDPH area-level data to calculate the cumulative fraction of unvaccinated individuals aged 20-64 years old on June 1, 2021 in the most recent zip code in which each staff member resided (see Appendix Table 1 for counts of included zip codes by prison). Second, we calculated the proportion of unvaccinated co-workers who worked in the same job classification (custody or healthcare) on the same shift, day, and prison as the staff member being analyzed. This variable was a composite, cross-sectional measure created by assigning a weight to each staff person's co-workers based on the total number of shifts worked together during the study period while either vaccinated (received at least 1 dose of Covid-19 vaccine) or unvaccinated (additional details in Supplementary Appendix).

\section{Statistical analysis}

We plotted vaccine uptake and detected prior infection among custody and healthcare staff (separately) over the study period. Next, for each prison, we compared proportions of staff and residents who remained unvaccinated at the end of the study period, and then examined the cumulative risk of detected Covid-19 among residents in those prisons in the 3 months following the study period (July 1, 2021 through September 25, 2021). We repeated this approach, comparing proportions and examining cumulative risk, after redefining the "vulnerable" groups of interest to include staff and residents who were neither vaccinated nor had history of prior detected infection by the end of the study period.

Finally, to identify characteristics of staff members who remained unvaccinated, we fit staff-level multivariable probit regression models (one each for custody and healthcare staff). The outcome variable in these models was remaining unvaccinated at the end of the study period. The control variables included 
medRxiv preprint doi: https://doi.org/10.1101/2021.11.18.21266535; this version posted November 19, 2021. The copyright holder for this

race/ethnicity, age group, gender, detected infection at any time prior to vaccination (including before the study period), and the variables constructed to measure levels of non-vaccination in each staff members' residential neighborhood and shift cohort, as described above. We also included an indicator of the shift most often worked (night, day, or swing), the number of shifts worked in the study period, and the average number of shifts worked on active weeks, as well as a prison fixed effect, indicating the prison at which a staff member worked most during the study period.

Results from the multivariable analyses are reported as the predicted probabilities that staff members in the groups of interest remained unvaccinated through June 30, 2021. For the continuous variables measuring proportion unvaccinated in residential zip codes and the shift cohorts, we report predicted values at the $25^{\text {th }}, 50^{\text {th }}$, and $75^{\text {th }}$ percentile of the distributions for custody and healthcare staff, respectively. All analyses were performed using Stata version 16.1.

\section{Role of the funding source}

This work was supported in part by the Covid-19 Emergency Response Fund at Stanford, established with a gift from the Horowitz Family Foundation; the National Institute on Drug Abuse; the Centers for Disease Control and Prevention through the Council of State and Territorial Epidemiologists; and the National Science Foundation Graduate Research Fellowship Programs. The funders had no role in the design of the analysis, interpretation of the data, or preparation, review or approval of the manuscript.

\section{Results}

\section{Prevalence of Vaccination and Prior Infection}

Uptake of Covid-19 vaccines among staff was brisk initially but plateaued within a couple of months. Figure 1 shows that from December 22, 2020 through February 15, 2021, coverage with at least 1 vaccine dose (blue and green shading) increased from $0 \%$ to $26 \%$ ( $0.5 \%$ per day) for custody staff and from $0 \%$ to $52 \%$ (1.0\% per day) for healthcare staff. Thereafter, the pace of vaccination coverage slowed, reaching 
medRxiv preprint doi: https://doi.org/10.1101/2021.11.18.21266535; this version posted November 19, 2021. The copyright holder for this preprint (which was not certified by peer review) is the author/funder, who has granted medRxiv a license to display the preprint in perpetuity. All rights reserved. No reuse allowed without permission.

$39 \%$ ( $0.3 \%$ per day) for custody staff and 64\% (0.5\% per day) for healthcare staff by June 30, 2021.

Figure 1 also shows that the surge in Covid-19 cases in the winter of 2020-21 was associated with substantial increases in the cumulative prevalence of confirmed Covid-19 cases among staff (green and yellow shading). Through December 22, 2020, CDCR had previously detected Covid-19 in 5\% of the custody staff in our study sample and $2 \%$ of healthcare staff; by June 30, 2021, these proportions had increased to $27 \%$ and $12 \%$, respectively. Seventy three percent of unvaccinated custody staff and $88 \%$ of unvaccinated healthcare staff had no recorded history of SARS-CoV-2 infection. (Appendix Figures 1 and 2 reproduce the information shown in Figure 1 for each prison).

Thus, $61 \%$ of custody staff and $37 \%$ of healthcare staff remained unvaccinated at the end of the study period. These proportions varied widely across the 33 prisons in our sample-from $37 \%$ to $86 \%$ among custody staff and from $26 \%$ to $79 \%$ among healthcare staff. Figure 2 (panels A and B) plots these proportions against proportions of unvaccinated residents (details provided in Appendix Table 2). Coverage among custody staff was lower than coverage among residents in every prison; this decrement ranged from 17 to 60 percentage points. Coverage among healthcare staff was lower than coverage among residents in all but one prison, with decrements ranging from to 1 to 48 percentage points. Prisons that had higher proportions of unvaccinated custody staff also tended to have higher proportions of unvaccinated healthcare staff (Spearman's rho: 0.57; $<<0.01$ ).

The cumulative proportion of residents at each prison who became infected in the three months following the study period ranged from $0 \%$ to $7.3 \%$ (mean: $0.8 \%$; 6 prisons above the mean) (Figure 2, Appendix Table 2). Of the 6 prisons with the largest proportions of residents infected in this 3-month period, 4 had above-average levels of unvaccinated custody staff, 4 had above-average levels of unvaccinated healthcare staff, and 5 had above-average levels of unvaccinated residents.

Patterns remained consistent when we refined the definition of the "vulnerable" population to include only individuals who remained unvaccinated and with no history of Covid-19 (Figure 2, panels C and D). 
medRxiv preprint doi: https://doi.org/10.1101/2021.11.18.21266535; this version posted November 19, 2021. The copyright holder for this preprint (which was not certified by peer review) is the author/funder, who has granted medRxiv a license to display the preprint in perpetuity. All rights reserved. No reuse allowed without permission.

\section{Correctional Staff and Predictors of Remaining Unvaccinated}

The study sample consisted of 31,089 prison staff employed at 33 prisons; 23,472 (75.5\%) of them were custody staff and 7,617 (24.5\%) were healthcare staff (Table 1). A majority were aged 30 to 49 years. Most custody staff were male (84\%), and most healthcare staff were female (71\%). Two thirds of custody staff were Hispanic (38\%) or white (28\%), while half of healthcare staff were Asian (28\%) or white $(23 \%)$

Among custody staff, $61 \%$ were unvaccinated (i.e., had received no doses of vaccine) and $72 \%$ had no confirmed Covid-19 by the end of June 2021. Among health care staff, $37 \%$ were unvaccinated and $88 \%$ had no confirmed infection. Custody staff resided in zip codes with a slightly higher rate of unvaccinated adults than healthcare staff did $(56 \%$ vs. $52 \%, \mathrm{p}<0.001)$, and had a much higher fraction of unvaccinated coworkers in their work cohorts $(60 \%$ vs. $34 \%, \mathrm{p}<0.001)$. The two types of workers had similar shift patterns.

Adjusted analyses showed a strong age gradient to vaccine uptake (Figure 3, Appendix Table 3, Appendix Table 4). For example, custody staff aged 18-29 years were 30 percentage points more likely to remain unvaccinated than their colleagues aged 60 years or older, while healthcare staff aged 18-29 years were 23 percentage points more likely to remain unvaccinated than their colleagues aged 60 years or older. Custody and healthcare staff with a history of Covid-19 were both 8 percentage points more likely to remain unvaccinated than their colleagues without such a history.

Residing in zip codes with relatively large proportions of unvaccinated 18-64 year-old residents was associated with slightly higher probability of remaining unvaccinated: 3 percentage points higher for custody staff, comparing the $75^{\text {th }}$ percentile to the $25^{\text {th }}$ percentile, and 6 percentage points higher for healthcare staff (both differences significant at the $\mathrm{p}<0.05$ level). Similarly, staff members who tended to share shifts with other staff that had lower levels of vaccination had a higher probability of remaining unvaccinated: 5 percentage points higher for custody staff, again comparing the $75^{\text {th }}$ percentile to the $25^{\text {th }}$ percentile, and 3 percentage points higher for healthcare staff (custody staff difference was significant at 
medRxiv preprint doi: https://doi.org/10.1101/2021.11.18.21266535; this version posted November 19, 2021. The copyright holder for this

the $\mathrm{p}<0.05$ level; healthcare staff difference was not). See the Supplementary Appendix for discussion of sensitivity analyses and presentation of results.

\section{Discussion}

This study found that vaccine coverage of staff working at California state prisons lagged far behind coverage of residents for the first half of 2021. Some prisons have relatively low rates of coverage for both staff and residents, creating substantial risks of ongoing outbreaks. Our results highlight the multifactorial nature of reasons for hesitancy - a function of demographic factors, community environment, peer behaviors, and no doubt other influences that our study was not designed to measure.

Personal decisions regarding vaccination are complex.(14) Among prison staff in California we detected evidence of multi-factorial explanations. Lower uptake among younger staff and those with a history of Covid-19 are consistent with findings from other settings and suggest perceptions of one's personal risk of infection or serious health consequences are influential.(15) The positive association we identified between low uptake and both working with unvaccinated staff and living in communities with low vaccination levels is not surprising. People are influenced by those around them, and seek out those whose beliefs align with their own. However, the risk such staff pose to residents is likely to be especially high, as they are at relatively high risk of acquiring SARS-CoV-2 infection and bringing it into the workplace. And while one might expect that in high transmission risk settings like prisons, staff would seek to protect themselves especially if those around them are less well protected via vaccination, our findings highlight the potential interplay of social dimensions and individual factors in the decision to obtain Covid-19 vaccination.

To address the risks posed by unvaccinated workers to vulnerable institutionalized populations, vaccine mandates have been enacted or proposed.(16) Although unions in these settings generally endorse vaccines, they oppose mandates and have fought them on picket-lines and in court. In California, vaccine mandates for state prison employees have come from two sources: the executive $b a \mathrm{nch}^{6}$ and the courts,(17) through an order issued in response to a request from the receiver charged with overseeing the 
medRxiv preprint doi: https://doi.org/10.1101/2021.11.18.21266535; this version posted November 19, 2021. The copyright holder for this

prison health system. However, both orders met stiff opposition from the prison guards' union and are currently mired in litigation.(18)

Our findings that correctional staff are more likely to remain unvaccinated if the people around them are unvaccinated suggests that important peer effects may be dampening vaccination uptake. Delivery of staff vaccination in the context of prisons, with or without a mandate, should be designed with peer effects in mind. For example, ensuring that individual staff members have access to vaccination in venues and at times where they can avoid being observed by their coworkers may be important. Likewise, as vaccination coverage increases in the prison and in particular staff groups (e.g., custody staff, night shift, etc.), communicating the current status of the cohort as a whole may help to shift staff member's perception of their peers' actions.

Our study has several limitations. First, generalizability to prisons outside California and to workers in other high-risk settings is unknown. Second, designing and implementing optimal strategies for boosting uptake of Covid-19 vaccines requires detailed understanding of the knowledge, beliefs, and preferences of the hesitant, and we did not measure these factors. Third, CDCR records may have missed vaccines obtained by some staff outside CDR's program. However, such misclassification is likely to have been uncommon because CDCR required notification and staff who did not show proof of vaccination were required to undergo a continuous testing regimen. Fourth, our measures of co-worker and home community influences are crude; studies with qualitative and mixed-method designs are better able to engage with the nuances of personal motivations. Finally, because of the rapid rollout and sharp uptake of vaccination among staff members who chose to get vaccinated, we were unable to analyze uptake decisions over time as a function of personal experiences with infection and co-worker vaccine decisions.

Despite ongoing risks of Delta-variant Covid-19 outbreaks in high-risk carceral settings like the state prisons of California, vaccination rates among prison staff continue to lag those of incarcerated residents. Younger staff, and staff who have had Covid-19, staff who are disproportionately opting to remain unvaccinated may be doing so in part because they perceive themselves to be at low risk of 
medRxiv preprint doi: https://doi.org/10.1101/2021.11.18.21266535; this version posted November 19, 2021. The copyright holder for this preprint (which was not certified by peer review) is the author/funder, who has granted medRxiv a license to display the preprint in perpetuity. All rights reserved. No reuse allowed without permission.

infection or disease relative to their older colleagues or those who have not had a prior infection.

However, social considerations both at home and at work also appear important, leading to some prisons and work cohorts with persistently below-average levels of staff vaccination. While effective and acceptable approaches to rapidly increasing vaccination coverage among correctional staff remain elusive, failing to develop and implement them prolongs very real health risks both to staff themselves, to the communities in which they reside, and to incarcerated residents.

With almost 1.2 million people currently residing in state and federal prisons in the United States, (19) addressing the risk of Covid-19 transmission and subsequent outbreaks, especially from highly transmissible viral variants like Delta, is a critical public health priority. Despite substantial levels of natural and acquired immunity in many incarcerated populations, Covid-19 risks continue to loom large, as evidenced by large summer outbreaks across California and Texas.(20, 21) 
medRxiv preprint doi: https://doi.org/10.1101/2021.11.18.21266535; this version posted November 19, 2021. The copyright holder for this preprint (which was not certified by peer review) is the author/funder, who has granted medRxiv a license to display the preprint in perpetuity.

\section{References}

1. Hawks L, Woolhandler S, McCormick D. COVID-19 in Prisons and Jails in the United States. JAMA Intern Med. 2020;180(8):1041-2. doi: 10.1001/jamainternmed.2020.1856. PubMed PMID: 32343355.

2. Saloner B, Parish K, Ward JA, DiLaura G, Dolovich S. COVID-19 Cases and Deaths in Federal and State Prisons. JAMA. 2020;324(6):602-3. doi: 10.1001/jama.2020.12528. PubMed PMID: 32639537; PubMed Central PMCID: PMC7344796.

3. Project TM. A State-by-State Look at Coronavirus in Prisons. June 9, 2021.

4. Wallace M, Hagan L, Curran KG, Williams SP, Handanagic S, Bjork A, et al. COVID-19 in Correctional and Detention Facilities - United States, February-April 2020. MMWR Morb Mortal Wkly Rep. 2020;69(19):587-90. Epub 20200515. doi: 10.15585/mmwr.mm6919e1. PubMed PMID: 32407300.

5. Project TCP. October 21, 2021. Available from: https://covidprisonproject.com/.

6. Chin ET, Ryckman T, Prince L, Leidner D, Alarid-Escudero F, Andrews JR, et al. COVID-19 in the California State Prison System: an Observational Study of Decarceration, Ongoing Risks, and Risk Factors. J Gen Intern Med. 2021;36(10):3096-102. Epub 20210721. doi: 10.1007/s11606-021-07022-x. PubMed PMID: 34291377; PubMed Central PMCID: PMC8294831.

7. Rehabilitation CDoCa. Population COVID - 19 Tracking: COVID - 19 Trends Aug 12, 2021. Available from: https://www.cdcr.ca.gov/covid19/population - status - tracking.

8. Wallace D, Eason JM, Walker J, Towers S, Grubesic TH, Nelson JR. Is There a Temporal Relationship between COVID-19 Infections among Prison Staff, Incarcerated Persons and the Larger Community in the United States? Int J Environ Res Public Health. 2021;18(13). Epub 20210626. doi: 10.3390/ijerph18136873. PubMed PMID: 34206845; PubMed Central PMCID: PMC8296880.

9. Scolforo M, Press A. Pennsylvania prison guard vaccinations increase after Wolf's mandate. Pittsburgh Post-Gazette. October 8, 2021.

10. Maslin Nir S. Their jobs made them get vaccinated. They refused. The New York Times. October 24, 2021.

11. Wiley $\mathrm{H}$, Venteicher $\mathrm{W}$. California can require correctional officers to get COVID vaccine, judge rules. The Sacramento Bee. October 18, 2021.

12. Rehabilitation CDoCa. Memorandum: Mandatory employee COVID-19 testing and noncompliance accountability. December 21, 2020.

13. Rehabilitation CDoCa. COVID-19 screening and testing matrix for patient movement. Revised June 2, 2021.

14. Jennings W, Stoker G, Bunting H, Valgarðsson VO, Gaskell J, Devine D, et al. Lack of Trust, Conspiracy Beliefs, and Social Media Use Predict COVID-19 Vaccine Hesitancy. Vaccines (Basel). 2021;9(6). Epub 20210603. doi: 10.3390/vaccines9060593. PubMed PMID: 34204971; PubMed Central PMCID: PMC8226842.

15. Aw J, Seng JJB, Seah SSY, Low LL. COVID-19 Vaccine Hesitancy-A Scoping Review of Literature in High-Income Countries. Vaccines (Basel). 2021;9(8). Epub 20210813. doi: 10.3390/vaccines9080900. PubMed PMID: 34452026; PubMed Central PMCID: PMC8402587.

16. Health CDoP. State public health officer order of July 26, 2021. Available from: https://www.cdph.ca.gov/Programs/CID/DCDC/Pages/COVID-19/Order-of-the-State-Public-HealthOfficer-Unvaccinated-Workers-In-High-Risk-Settings.aspx.

17. Gafni M. Judge orders California prison guards to get vaccinated. The San Francisco Chronicle. September 27, 2021.

18. Venteicher W. California judge blocks COVID-19 vaccine order for correctional officers. The Sacramento Bee. October 14, 2021.

19. Law U. Covid Behind Bars Data Project 2021. Available from: https://uclacovidbehindbars.org/. 
medRxiv preprint doi: https://doi.org/10.1101/2021.11.18.21266535; this version posted November 19, 2021. The copyright holder for this preprint (which was not certified by peer review) is the author/funder, who has granted medRxiv a license to display the preprint in perpetuity. All rights reserved. No reuse allowed without permission.

20. Chin ET, Leidner D, Zhang Y, Long E, Prince L, Li Y, et al. Effectiveness of the mRNA-1273 Vaccine during a SARS-CoV-2 Delta Outbreak in a Prison. N Engl J Med. 2021. Epub 20211020. doi: 10.1056/NEJMc2114089. PubMed PMID: 34670040.

21. Hagan LM, McCormick DW, Lee C, Sleweon S, Nicolae L, Dixon T, et al. Outbreak of SARS-CoV-2 B.1.617.2 (Delta) Variant Infections Among Incarcerated Persons in a Federal Prison - Texas, July-August 2021. MMWR Morb Mortal Wkly Rep. 2021;70(38):1349-54. Epub 20210924. doi:

10.15585/mmwr.mm7038e3. PubMed PMID: 34555009; PubMed Central PMCID: PMC8459894. 
medRxiv preprint doi: https://doi.org/10.1101/2021.11.18.21266535; this version posted November 19, 2021. The copyright holder for this preprint (which was not certified by peer review) is the author/funder, who has granted medRxiv a license to display the preprint in perpetuity.

Table 1. Individual and shift characteristics of the study sample of custody and healthcare direct-care staff at 33 California state prisons

\begin{tabular}{|c|c|c|c|c|c|}
\hline \multicolumn{2}{|c|}{ 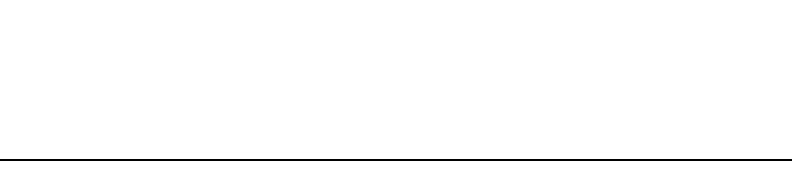 } & \multicolumn{2}{|c|}{$\begin{array}{c}\text { Custody Staff } \\
(\mathrm{N}=23,472) \\
\mathrm{n}(\%)\end{array}$} & \multicolumn{2}{|c|}{$\begin{array}{c}\text { Health Staff } \\
(\mathrm{N}=7,617) \\
\mathrm{n}(\%)\end{array}$} \\
\hline \multicolumn{2}{|c|}{ Individual Characteristics } & & & & \\
\hline \multirow[t]{5}{*}{ Age category } & $18-29$ & 2,862 & $(12 \%)$ & 422 & $(6 \%)$ \\
\hline & $30-39$ & 7,724 & $(33 \%)$ & 2,076 & $(27 \%)$ \\
\hline & $40-49$ & 7,765 & $(33 \%)$ & 2,362 & $(31 \%)$ \\
\hline & $50-59$ & 4,310 & $(18 \%)$ & 1,886 & $(25 \%)$ \\
\hline & $60+$ & 811 & $(3 \%)$ & 871 & $(11 \%)$ \\
\hline \multirow[t]{5}{*}{ Race } & Black & 1,571 & $(7 \%)$ & 1,201 & $(16 \%)$ \\
\hline & Hispanic & 9,008 & $(38 \%)$ & 1,409 & $(18 \%)$ \\
\hline & White & 6,666 & $(28 \%)$ & 1,771 & $(23 \%)$ \\
\hline & Other/Unknown & 4,773 & $(20 \%)$ & 1,088 & $(14 \%)$ \\
\hline & Asian/PI & 1,454 & $(6 \%)$ & 2,148 & $(28 \%)$ \\
\hline \multirow[t]{2}{*}{ Gender } & Female & 3,751 & $(16 \%)$ & 5,434 & $(71 \%)$ \\
\hline & Male & 19,721 & $(84 \%)$ & 2,183 & $(29 \%)$ \\
\hline \multicolumn{2}{|c|}{ No history of Covid-19 before June 30, 2021} & 17,052 & $(73 \%)$ & 6,692 & $(88 \%)$ \\
\hline \multicolumn{2}{|c|}{ Remained unvaccinated through June 30, 2021} & 14,369 & $(61 \%)$ & 2,822 & $(37 \%)$ \\
\hline \multicolumn{2}{|c|}{$\begin{array}{l}\text { Fraction of 20-64 year-olds vaccinated in zip code of } \\
\text { residence (mean/SD) }\end{array}$} & $56 \%$ & $(12 \%)$ & $52 \%$ & $(13 \%)$ \\
\hline \multicolumn{6}{|c|}{ Institution/Work Shift Characteristics } \\
\hline \multicolumn{2}{|c|}{ Fraction of shift co-workers not vaccinated (mean/SD) } & $60 \%$ & $(11 \%)$ & $34 \%$ & $(10 \%)$ \\
\hline \multirow[t]{3}{*}{ Most worked shift } & Night & 3,170 & $(14 \%)$ & 699 & $(9 \%)$ \\
\hline & Day & 13,510 & $(58 \%)$ & 5,014 & $(66 \%)$ \\
\hline & Swing & 6,792 & $(29 \%)$ & 1,904 & $(25 \%)$ \\
\hline \multicolumn{2}{|c|}{ Number of shifts during study period (mean/SD) } & 126 & $(28)$ & 123 & $(45)$ \\
\hline \multicolumn{2}{|c|}{ Number of shifts/week (mean/SD) } & 4.7 & $(0.84)$ & 4.6 & $(1.32)$ \\
\hline
\end{tabular}

The analytic dataset includes 31,089 custody or healthcare staff who worked at least five direct-care shifts between April, May, and June 2021 and at least 1 direct-care shift in each of those months in any one of 33 CDCR prisons. No history of Covid-19 indicates no positive result on any PCR or antigen diagnostic test for SARS-CoV-2 infection prior to first dose of vaccination, or before the end of the study period for unvaccinated. Vaccination rates of zip code of residence are based on cumulative CDPH vaccination rates as of June 1, 2021 in the zip code where the staff person lived on the most recent recorded work shift. Fraction of co-workers not vaccinated is a count of all co-workers by date, shift, prison and is weighted by the number of shifts worked with a given coworker. Number of shifts worked and number of shifts per week are based on shifts worked between December 22, 2020 and June 30, 2021 (for the latter, weeks in which there were zero shifts worked were excluded in calculation). 
Figure 1: Cumulative vaccination and history of Covid-19 infection rates for custody and healthcare staff

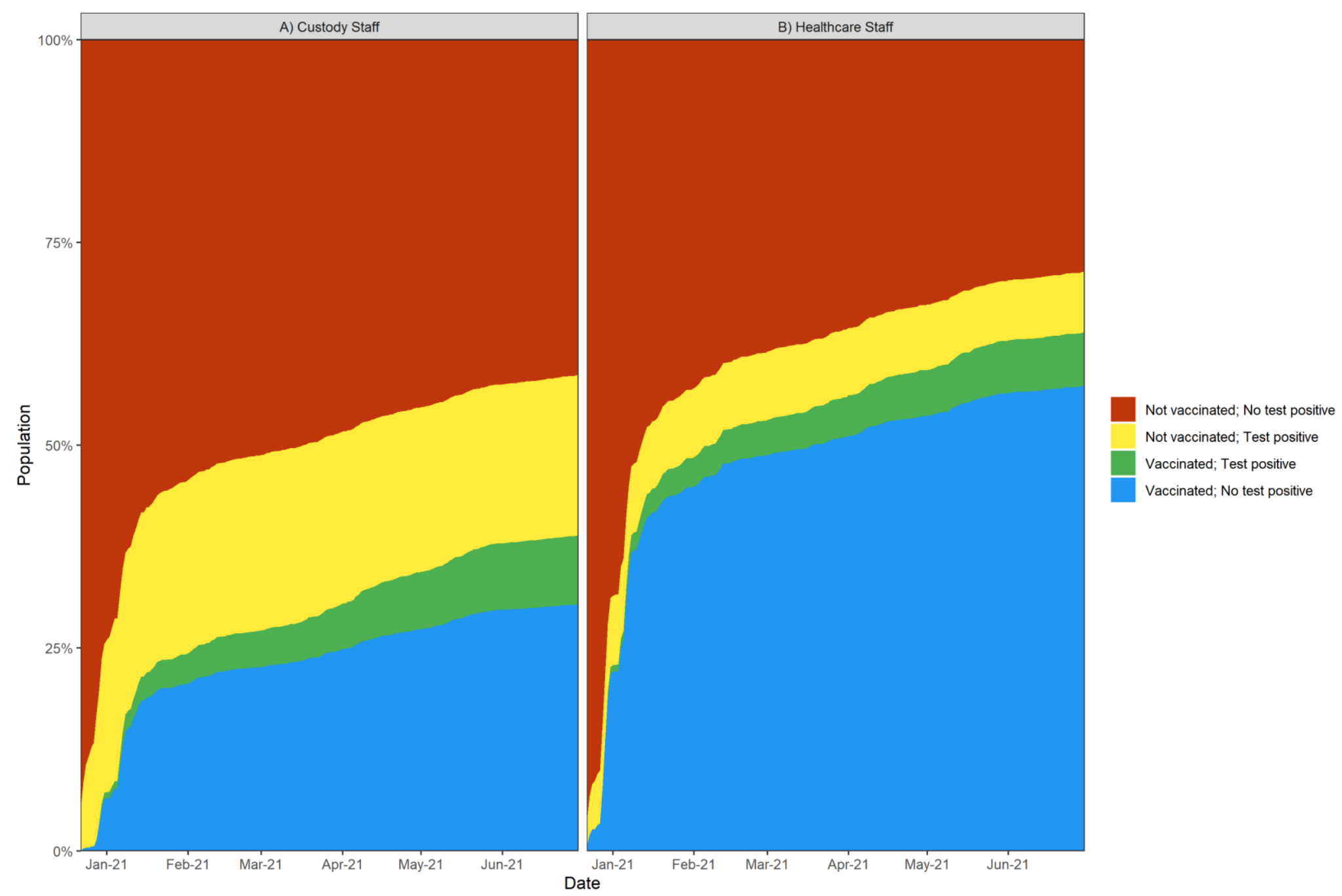

Cumulative counts among custody and healthcare direct-care staff who had active shifts in June 2021 ( $N=23,472$ for custody and $N=7,617$ for healthcare staff). Vaccinated indicates receipt of 1 or more doses of any Covid-19 vaccine and not vaccinated indicates receipt of zero doses of vaccine as of a given date. No test positive indicates no positive result for a recorded test for SARS-CoV-2 infection as of a given date. Test positive indicates at least one recorded positive test for infection as of a given date. Not vaccinated; no test positive represents the fraction of staff who remained unvaccinated and without a test positive through a given date. Counts do not reflect the order of vaccine uptake and SARS-CoV-2 infection, rather they shift proportionately as staff members move from category to category. 
Figure 2: Percentage of custody staff, healthcare staff, and residents of California state prisons who are unvaccinated and have not previously tested positive for SARS-CoV-2, by prison on June 30, 2021 and cumulative incidence of infection among residents from July 1, 2021 through September 25, 2021

A) Custody

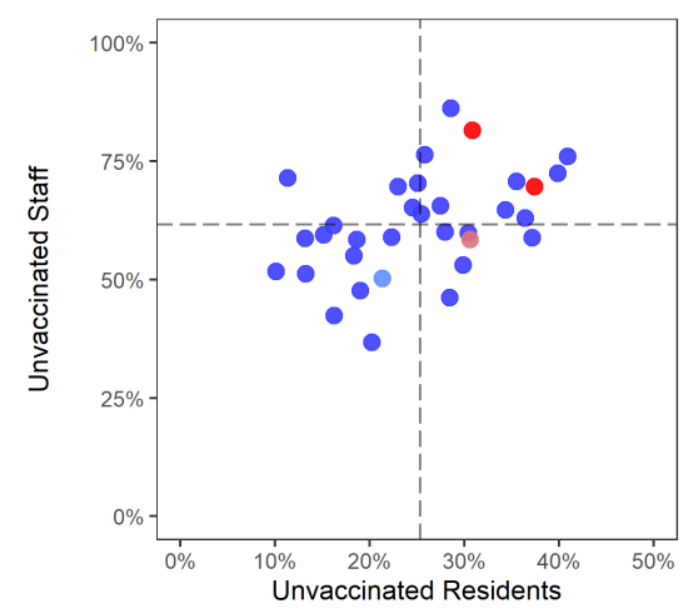

C) Custody

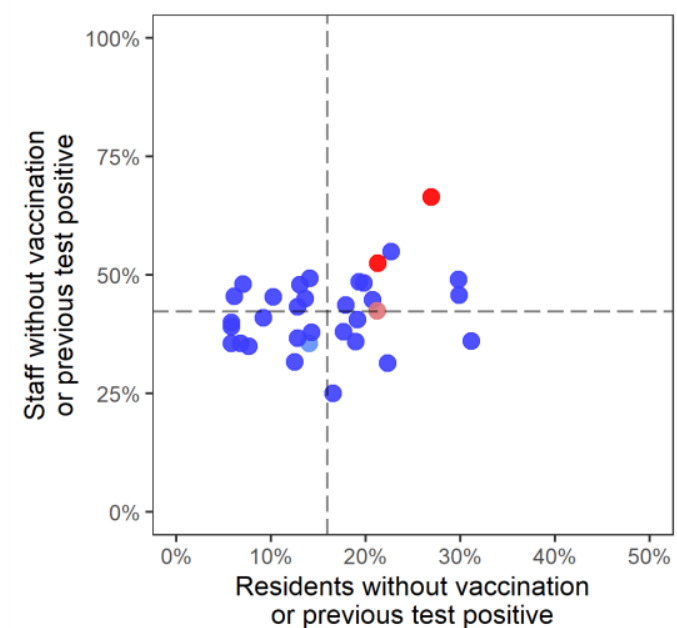

B) Healthcare

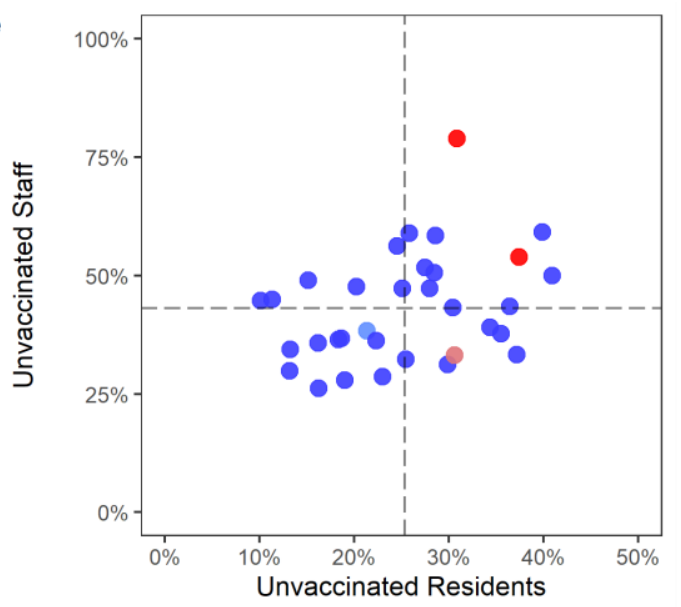

D) Healthcare

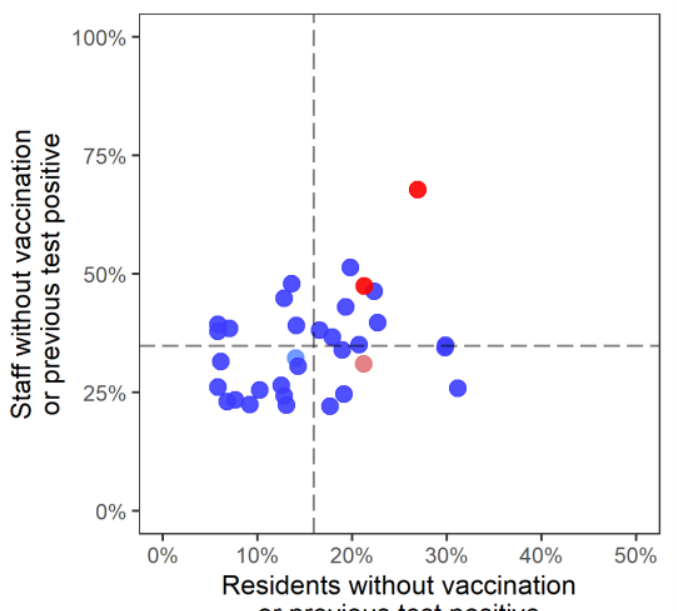

or previous test positive

Cum. incidence

for residents (\%)

$1.0 \quad 2.5 \quad 5.0$

Proportions of unvaccinated custody and healthcare staff and residents (Panels A and B) and proportions of unvaccinated custody and healthcare staff and residents who also have no previous positive test (Panels $C$ and D) as of June 30, 2021 at each of 33 CDCR prisons. Cumulative incidence for residents is based on total incidence of SARS-CoV-2 infection between July 1, 2021 and September 25, 2021. Vaccinated indicates receipt of 1 or more doses of any Covid-19 vaccine and not vaccinated indicates receipt of zero doses of vaccine. 
Figure 3: Predicted probabilities of remaining unvaccinated through June 30, 2021 for Custody and Healthcare Staff from the multivariable regression models

A) Custody Staff

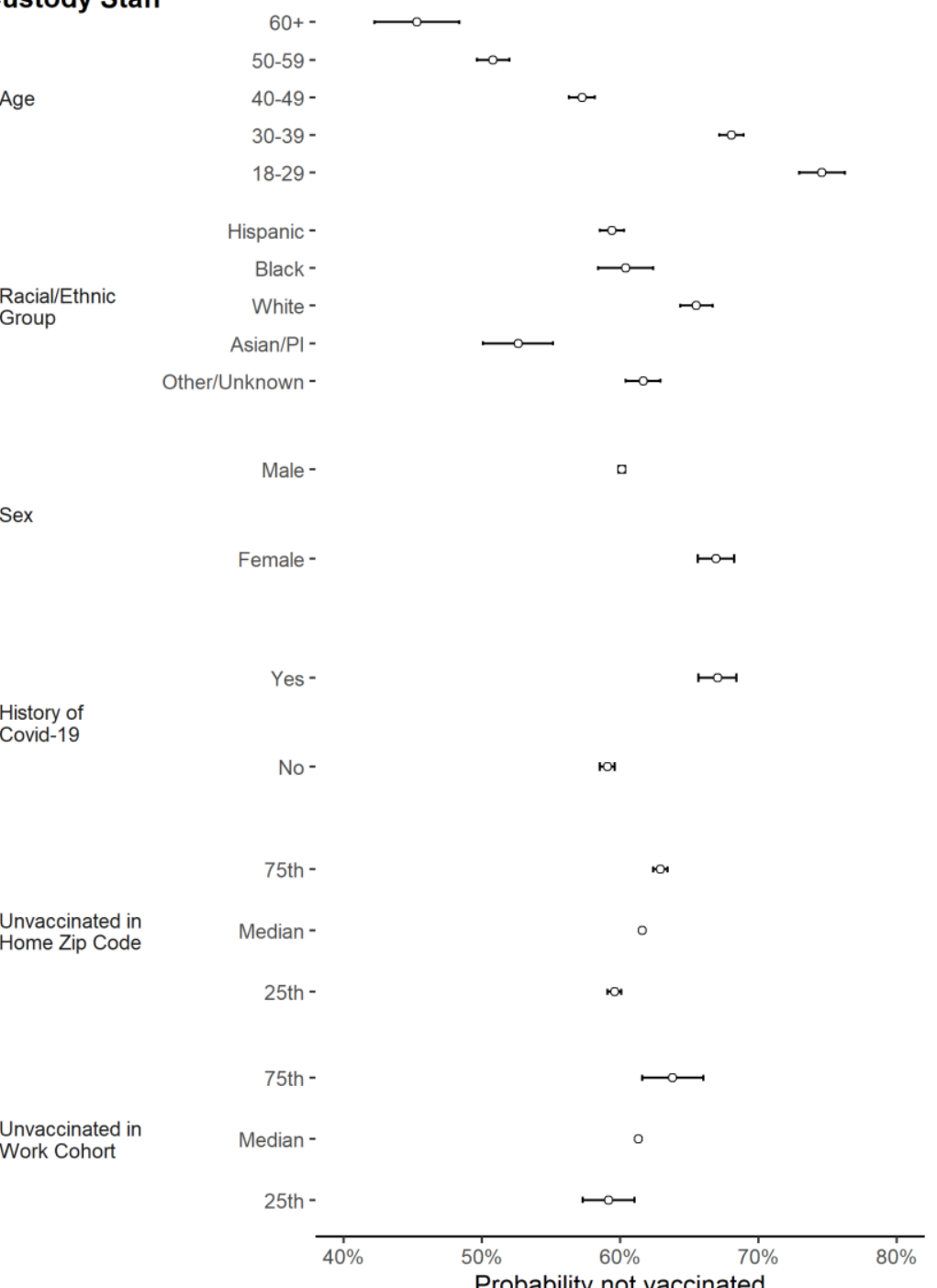

B) Healthcare Staff

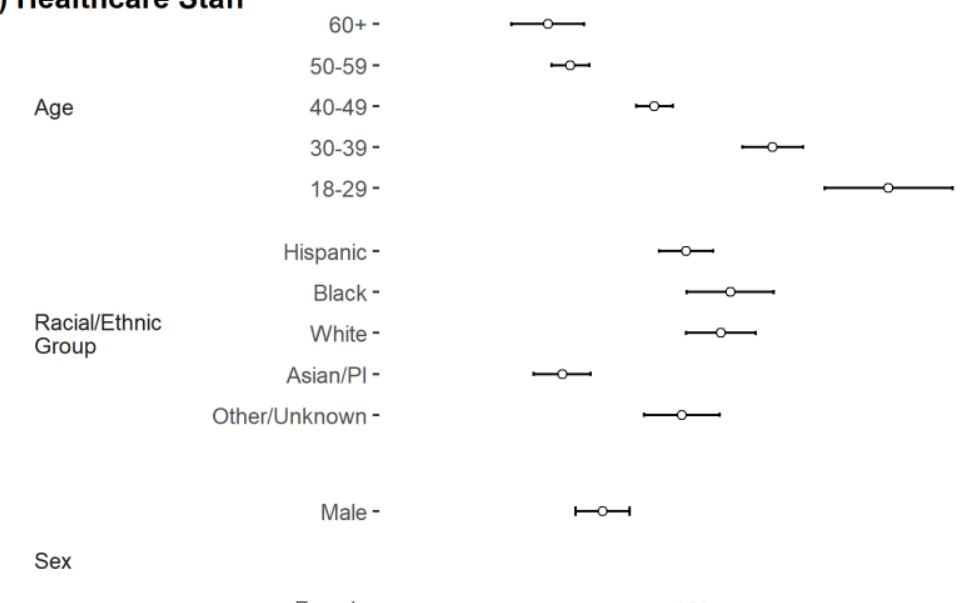

Female -
Yes

$$
\text { No- }
$$

75th -

Unvaccinated in Home Zip Code

Unvaccinated in

Median -

$$
\text { 25th - }
$$

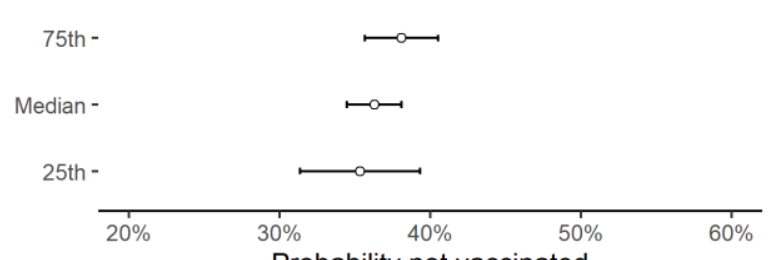

Panel A and Panel B show predicted probability (average adjusted margins) of being unvaccinated by June 30,2021 for custody staff ( $\mathrm{N}=23,472$ ) and healthcare staff $(N=7,617)$ respectively and was estimated using a multivariable probit model with robust standard errors, clustering on the main prison of employment. History of Covid-19 indicates a positive result on any PCR or antigen diagnostic test for SARS-CoV-2 infection during the study period. Vaccination rates of zip 
code of residence are based on cumulative CDPH vaccination rates as of June 1st in the zip code where the staff person lived on the most recent work-shift. Fraction of co-workers not vaccinated is a count of all co-workers by date, shift, prison and is weighted by the number of shifts worked with a given co-worker. The model controlled for all variables presented in the figure as well as an indicator of the shift (night, day, or swing) most often worked, the number of shifts worked in the study period, the average number of shifts worked on active weeks, and prison fixed effects, representing the main prison in which a staff member worked during the study period. For unvaccinated in home zip code and unvaccinated in work cohort, which are continuous variables in our model, we predict at the $25^{\text {th }}, 50^{\text {th }}$ and $75^{\text {th }}$ percentiles $(49 \%, 57 \%$, and $63 \%$ for the former and $53 \%, 59 \%$, and $67 \%$ for the latter for custody staff; $44 \%, 53 \%$, and $61 \%$ for the former and $26 \%, 31 \%$ and $39 \%$ for the latter for healthcare staff). 